\title{
Strategi pengembangan bakso kerang sebagai upaya peningkatan perekonomian masyarakat desa kedungrejo kecamatan muncar
}

\section{Mussels meatballs development strategy as an effort to improve the economy of the Kedungrejo village communities subdistrict Muncar}

\author{
Tita Divya Carolin ${ }^{1}$, Asfarina Hidayah ${ }^{2}$ \\ ${ }^{1}$ Program Studi Teknik Industri, Fakultas Teknik, Universitas 17 Agustus 1945 Banyuwangi Jalan \\ Adi Sucipto no 26, Banyuwangi, Jawa Timur, Indonesia \\ ${ }^{2}$ Program Studi Teknik Industri, Fakultas Teknik, Universitas 17 Agustus 1945 Banyuwangi Jalan \\ Adi Sucipto no 26, Banyuwangi, Jawa Timur, Indonesia \\ Email: titadivyacaroline@gmail.com, asfarina@untag-banyuwangi.ac.id
}

Submitted: 22 June 2021 Revised: 09 July 2021 Accepted: 22 July 2021 Publish: 31 July 2021

\begin{abstract}
Abstrak
Desa Kedungrejo adalah salah satu desa yang berlokasi di Kecamatan Muncar, Banyuwangi. Desa ini terkenal dengan Penghasil Ikan Laut terbesar di Jawa Timur sejak tahun 2010. Hal ini karena letak wilayahnya yang dekat sekali dengan pesisir laut sehingga mayoritas penduduk disana adalah nelayan. Kawasan desa ini terkenal sebagai pusat perindustrian yang berhubungan dengan hasil lautnya, seperti industri pengalengan ikan, industri produksi pakan ternak, dan sebagainya. Salah satu hasil tangkapan laut dari nelayan Desa Kedungrejo adalah kerang laut. Salah satu cara untuk mendukung pertumbuhan ekonomi di Desa Kedungrejo adalah dengan memaksimalkan potensi Desa yang terkenal dengan sektor kelautannya. Tujuan penelitian ini dilakukan adalah untuk mendukung prekonomian Desa Kedungrejo dengan cara mengembangkan UMKM yang berhubungan dengan hasil laut. Metode penelitian yang digunakan adalah dengan teknik pengumpulan data dan deskriptif analisis metode SWOT. Dari penelitian ini menghasilkan suatu produk Baskerang (Bakso Kerang) yang berpeluang sangat besar karena belum banyak dikenal banyak kalangan.
\end{abstract}

Keyword : bakso kerang, peningkatan ekonomi, Muncar

\begin{abstract}
Kedungrejo Village is one of the villages located in Muncar District, Banyuwangi. This village is known as the largest marine fish producer in East Java since 2010. This is because the area is very close to the sea coast so that the majority of the population there are fishermen. This village area is famous as an industrial center related to marine products, such as the fish canning industry, animal feed production industry, and so on. One of the marine catches from fishermen in Kedungrejo Village is sea shells. One way to support economic growth in Kedungrejo Village is to maximize the potential of the village which is famous for its marine sector. The purpose of this research is to support the economy of Kedungrejo Village by developing MSMEs related to marine products. The research method used is data collection techniques and descriptive SWOT analysis method. From this research, it produces a Baskerang (Scallop Meatball) product which has a very large opportunity because it is not widely known by many circles.

Keyword : clam meatballs, economic improvement, Muncar
\end{abstract}




\section{PENDAHULUAN}

Desa Kedungrejo adalah salah satu dari 10 Desa di Kecamatan Muncar Kabupaten Banyuwangi, Jawa Timur. Desa ini luasnya \pm 668.472 Ha dengan batas wilayah kelelawar terletak di bagian timur kabupaten Banyuwangi kurang lebih $45 \mathrm{~km}$ dari jantung kota Banyuwangi, sebelah Utara Desa Tembokrejo, Sebelah Barat Desa Blambangan dan Desa Tapan Rejo, Sebelah Selatan Desa Kedungringin dan Sebelah Timur berbatasan langsung dengan selat Bali.

Dahulu Desa Kedungrejo sangat lumrah dikenal dengan nama Muncar, sebelum menjadi Desa Kedungrejo, Muncar adalah merupakan salah satu desa yang berada di wilayah kecamatan Cluring. Dengan perkembangan waktu kecamatan Cluring terpecah menjadi beberapa bagian dan muncul kecamatan baru yang bernama kecamatan Muncar. Sebagian penduduk Desa Kedungrejo , Muncar adalah pendatang dari berbagai suku atau ras. Sebagian penduduknya berasal dari suku bugis (sulawesi selatan), Madura dan beberapa daerah di wilayah Jawa.
Arti nama kedungrejo berasal dari bahasa jawa yaitu "kedung" berarti sumber air yang luas, dan "Rejo" berarti ramai, sehingga diartikan bahwa Desa ini terdapat sumber udara yang luas yaitu Laut dengan segala sumberdaya yang ada didalamnya. Kedung atau sumber tersebut semakin lama semakin Rejo atau ramai dengan segala bentuk aktifitas kehidupan di dalamnya. Desa Kedungrejo merupakan desa yang memiliki banyak potensi kekayaan alam yang banyak sekali terutama kekayaan alam yang berasal dari laut. Letak desa yang dekat sekali dengan laut membuat sebagian besar mayoritas penduduk di sana berprofesi sebagai nelayan. Hal ini membuat Desa tersebut merupakan Desa pesisir penghasil ikan laut terbesar di Jawa Timur.

Sejak tahun 2010 hasil tangkapan ikan nelayan mengalami penurunan. Untuk mengembangkan perekonomian Desa Kedungrejo, Masyarakat atau warga desa tersebut memiliki pekerjaan yang dapat membatu dalam mengembangkan perekonomian desa. Sebagian warga Desa Kedungrejo bekerja dalam bermacammacam sektor. Masyarakat bekerja sebagai petani dalam sektor pertanian dan 
perkebunan, nelayan dalam sektor perikanan serta terdapat juga masyarakat yang membuka usaha kecil (UMKM).

Strategi pemasaran adalah rangkaian upaya yang dilakukan oleh perusahaan guna mencapai tujuan yang diinginkan oeh suatu perusahaan tersebut. Strategi pemasaran memiliki peranan yang penting dalam sebuah perusahaan ataupun bisnis karena berfungsi untuk menentukan nilai ekonomi perusahaan, baik itu harga barang maupun jasa, yaitu: produksi, pemasaran, konsumsi.

Tahun 2020 hingga saat ini Indonesia dan seluruh dunia dilanda pandemi COVID-19. Virus tersebut tidak hanya menyerang kesehatan manusia melainkan seluruh aspek kehidupan. Aspek ekonomi adalah salah satu aspek yang terdampak virus COVID-19. Akibat pandemi tersebut melumpuhkan perekonomian Indonesia termasuk di Desa Kedungrejo, Muncar. Sebagai dampaknya adalah adanya penerununan penjualan dalam sektor pertanian, perikanan dan UMKM.

Untuk mendukung perkembangan perekonomian di Desa Kedungrejo, Muncar perlu adanya analisis strategi pemasaran yang sesuai dengan standar agar bisa membangun serta mendukung perekonomian sehingga dengan penelitian ini kami mengangkat judul "Strategi Pengembangan Bakso Kerang Sebagai Upaya Peningkatan Perekonomian Masyarakat Desa Kedungrejo Kecamatan Muncar”.

\section{METODE PENELITIAN}

Penelitian ini dilaksanakan di Desa Kedungrejo, Kecamatan Muncar Banyuwangi pada tanggal 27 Maret 2021 dengan menggunakan teknik pengumpulan data dan deskriptif analisis dengan metode SWOT. dalam menerapkan strategi pemasaran hal utama yang harus dipertimbangkan adalah analisis SWOT untuk menganalisis dan mengidentifikasi berbagai faktor secara sistematis untuk merumuskan strategi berdasarkan pada logika yang dapat memaksimalkan kekuatan (strengths), peluang (opportunity), namun secara bersamaan meminimalkan kelemahan (weakness) dan ancaman (threat).

\section{HASIL DAN PEMBAHASAN}

Kawasan Desa Kedungrejo yang letak wilayahnya dekat sekali dengan 
pesisir pantai laut terkenal dengan pusat perindustrian yang berhubungan dengan hasil lautnya, seperti industri pengalengan ikan, industri produksi pakan ternak, dan sebagainya. Salah satu tangkapan laut dari nelayan Desa Kedungrejo adalah kerang laut. Maka dari itu, potensi kerang laut ini dimanfaatkan dengan cara diolah menjadi produk yang dapat meningkatkan perkembangan ekonomi di Desa Kedungrejo.

\section{Analysis SWOT}

STRENGTH (Kekuatan)

- Kelebihan produk, produk baserang memiliki manfaat dan keunggulan untuk dikonsumsi karena mengandung banyak gizi seperti protein, lemak, asam lemak omega-3, zat besi, vitamin A, vitamin B12, Vitamin C, Kalsium, Kalium, Mangan, Selenium dan Karbohidrat. Kerrang juga bermanfaaat untuk mengatasi anemia, menjaga Kesehatan jantung, membentuk dan merawat otot, mencegah kerusakan saraf, dan menjaga sistem imun. Harga produk juga sangat murah dan ekonomis.
- Kreativitas, kemasan yang digunakan terbuat dari material plastic, nylon, alumunium foil, dan kertas dengan sistem ziplock sehingga memungkinkan konsumen untuk menggunakan produk sesuai keperluan apabila produk masih tersisa sehingga dapat ditutup kembali. Hal ini juga dapat menjaga produk dari pengaruh keadaan luar kemasan sehingga bentuk, rasa dan aromanya tidak berubah dan akan tetap sama seperti saat awal dikemas. Selain itu kemasan yang tertutup rapat dapat melindungi produk dari serangga dan bakteri yang masuk kedalam kemasan.

- Bahan baku yang mudah didapat, bahan baku baskerang adalah kerang yang banyak tersedia dengan harga yang terjangkau. Hal ini karena Desa kedungrejo memiliki potensi penghasil kerang yang melimpah.

\section{WEAKNESS (Kelemahan)}

- Produk merupakan inovasi makanan yang masih belum lumrah atau jarang diketahui oleh kalangan luas.

- Belum memiliki cukup pengalaman dalam memulai usaha bisnis 
Journal of Aquaculture Science

DOI: https://doi.org/10.31093/joas.v6i1IS.154

baskerang sehingga perlu

ditingkatkan.

OPPORTUNITIES (Peluang)

- Masyarakat indonesia terkenal sebagai masyarakat yang suka sekali makan makanan ringan atau "ngemil". Sehingga produk ini sangat cocok untuk dijual di kalangan luas dan menjadi inovasi cita rasa baru bagi masyarakat pada umumnya. Selain itu, prduk juga mengandung gizi yang bermanfaat bagi tubuh.

- Pemasaran yang dilakukan secara online melalui sosial media dan market place sehingga dapat menjangkau berbagai segmen konsumen.

\section{THREATS (Ancaman)}

- Ancaman yang dimiliki produk adalah karena produk ini merupakan inovasi baru yang masih terlalu awam atau belum banyak diketahui oleh kalangan luas. Selain itu, konsumen juga lebih tertarik dengan produk yang modern, import, viral dan lebih kekinian.

\section{Strategi Pemasaran}

July 2021 Vol 6 Issue Spesial: 37-43

Online pada http://joas.co.id

Produk merupakan segala sesuatu yang dapat ditawarkan kepada pasar untuk mendapatkan perhatian, dimiliki, digunakan atau dikonsumsi sehingga dapat memuaskan harapan dan kebutuhan konsumen. (Kotler, 2000). Produk Baskerang termasuk produk yang dapat dikonsumsi oleh pelanggan di mana termasuk dalam produk kebutuhan seharihari yang mampu dibeli dan dikonsumsi secara rutin oleh konsumen.

Terdapat 2 jenis kemasan standing food yang memiliki berat yang berbeda. Harga produk Baskerang dalam kemasan berisi 90 gram adalah Rp 10.000,00. Dan kemasan yang berisi 45 gram adalah $\mathrm{Rp}$ 3.000,00. Dengan harga yang terbilang murah, produk yang diterima konsumen jelas sangat murah dan berkualitas.

Lokasi penjualan yang berada di SMK Miftahul Ulum Muncar bermanfaat untuk mendapatkan keuntungan melalui siswa-siswi yang gemar ngemil sehingga profit keuntungan dapat maksimal. Selain itu sasaran dan target pasar juga dilakukan melalui sosial media, took sekitar sekolah dan diperkenalkan dalam galeri produk SMK se-Jawa Timur.

Di masa pandemi akibat Covid-19 terjadi penurunan penjualan. Penjualan 
produk di Kopsis sekolah sekitar Kecamatan Muncar yang biasanya terjual sebanyak $70 \%$ menjadi hanya terjual sebanyak 30\% saja. Sehingga penulis membuat strategi pemasaran sebagai pendukung perekonomian Desa Kedungrejo Kecamatan Muncar.

\section{1) Pengembangan Produk}

Diproduksi dengan bahan yang berkualitas baik dan pengemasan yang aman serta ekonomis. Dengan demikian, produk baskerang diharapkan menjadi makanan ringan yang digemari oleh seluruh masyarakat.

\section{2) Pengembangan Wilayah Pemasaran}

Pemasaran tidak hanya di kawasan sekolah saja tetapi juga di Kawasan Desa Kedungrejo dan desa sekitarnya. Pemasarannya kemudian meluas menuju pusat kota Banyuwangi dengan memperkenalkan produk sebagai makanan khas dari Desa Kedungrejo. Dengan demikian pemasaran produk akan terus meluas dan produk akan lebih dikenal oleh khalayak umum.

3) Kegiatan Promosi

Promosi dilakukan dengan memberikan tester kepada orang terdekat yang berpotensi menjadi konsumen. Promosi kemudian melalui media online seperti $e$ commerce dan sosial media yang dapat dijangkau masyarakat luas, baik dari dalam maupun dari luar negeri. Promosi dibuat dengan sangat menarik serta informatif sehingga menarik konsumen untuk membeli.

\section{KESIMPULAN}

Desa kedungrejo Kecamatan Muncar adalah desa Pesisir yang memiliki kekayaan laut yang sangat berlimpah salah satunya adalah kerang. Kerang dimanfaatkan dengan cara diolah menjadi produk yang dapat meningkatkan perkembangan ekonomi di Desa Kedungrejo. Akibat pandemi Covid-19 banyak menyerang seluruh aspek kehidupan terutama aspek ekonomi yang menurunkan penjualan dalam sektor pertanian, perikanan, dan UMKM. Dengan melakukan kegiatan pengembangan produk yang memiliki peluang jual tinggi terciptalah produk inovasi dari kekayaan alam berupa kerang yaitu bakso goreng kerang "Baskerang". Dengan menggunakan bahan-bahan dan kemasan yang berkualitas serta menarik. 
Journal of Aquaculture Science

DOI: https://doi.org/10.31093/joas.v6i1IS.154
July 2021 Vol 6 Issue Spesial: 37-43

Online pada http://joas.co.id
Strategi pemasaran yang digunakan adalah dengan melakukan pengembangan dari segi jangkauan pemasaran produk agar dapat menembus seluruh pasar sekitar desa, sekitar kota, bahkan hingga di wilayah dalam dan luar negeri. Pemasaran juga dapat dilakukan melalui media online seperti media sosial, platform situs jual beli online (ecommerce) sehingga mampu menjadi strategi yang unggul untuk mendukung perkembangan ekonomi bagi masyarakat Desa Kedungrejo.

\section{Ucapan Terima Kasih}

Dalam penyusunan penelitian ini tidak terlepas dukungan dari berbagai pihak. Peneliti secara khusus mengucapkan terima kasih yang sebesarbesarnya kepada semua pihak yang telah membantu. Peneliti banyak menerima bimbingan, petunjuk dan bantuan serta dorongan dari berbagai pihak baik yang bersifat moral maupun material. Pada kesempatan ini penulis menyampaikan rasa terima kasih yang sebesar-besarnya kepada UMKM Mumbay Bahari dan masyarakat Desa Kedungrejo Kecamatan Muncar, sehingga penelitian ini terlaksana dengan baik, lancer dan sukses.

\section{Daftar Pustaka}

M. Indri, “Analisis SWOT Dalam Menentukan Strategi Pemasaran," Ilmu Manaj., vol. 17, 2020.

Mufreni, "Pengaruh Desain Produk, Bentuk Kemasan, dan Bahan Kemasan terhadap Minat beli Konsumen,” J. Ekon. Manaj., vol. 2, 2016.

K. Kurniawan, "9 Strategi Pemasaran 2020: Cara Membuat Strategi Pemasaran" 2020. https://projasaweb.com/strategipemasaran/.

M. H. Khoirudin, "Implementasi Strategi Pemasaran Berbasis Internet Marketing Untuk Meningkatkan Pendapatan," Ekon. dan Bisnis Islam, vol. 3, 2020.

P. Lestari, "Implementasi Strategi Promosi Produk dalam Proses Keputusan Pembelian melalui Digital Marketing saat Pandemi Covid'19," Manaj. Inov., vol. 3, 2020.

Vellin Melvina, ddk. 2021. "Strategi Pemasaran Keripik Ikan Layur sebagai Pendukung Perekonomian Desa Songbanyu, Kecamatan Girisubo, Gunung Kidul", Yogyakarta. 